DOI: 10.1515/rpp-2016-0017

$\mathrm{PhD}$ in Philological Sciences, Associate Professor, OLGA NAGORNA

Khmelnytskyi University of Management and Law Address: 8 Heroiv Maidanu St., Khmelnytskyi, 29013, Ukraine

E-mail: olha-nahorna@yandex.ru

\title{
SOCIO-PEDAGOGICAL PORTRAIT \\ OF A MASTER'S DEGREE STUDENT IN INTERNATIONAL ARBITRATION: EXPERIENCE OF GREAT BRITAIN
}

\begin{abstract}
International arbitration as the efficient means of alternative dispute resolution has become, due to globalization, a highly specialised service rendered by professionals. Master's degree program (LLM) completion enables those interested to become competent and competitive specialists in arbitration on the international arena. Great Britain has accumulated broad practical experience in organizing professional training in the field of international arbitration. Many leading British universities offer prospective students Master's programs in this speciality, encouraging all comers, even those with the initial non-legal background. Basic competences of LLM graduates in international arbitration (systemic competences, professional instrumental competences, professional social and personal competences) have been identified and clarified on the basis of relevant sources analysis. Professionally important knowledge, abilities and skills have been generalized and explained. For instance, an international arbitration LLM graduate is obliged to possess communicative and social skills, cognitive abilities and skills in the subject area, must be competent in English law, etc.

Key words: Master's degree student, international arbitration, arbitrator, university education, professional, competence, knowledge, ability, skill.

\section{INTRODUCTION}

International arbitration has recently obtained much importance, especially for commercial disputes.

Professionals who are involved in the sphere of international arbitration are referred to as Alternative Dispute Resolution Coordinators (ADR Coordinators), Alternative Dispute Resolution Mediators (ADR Mediators), Arbiters, Arbitrators, Commissioners, Labor Arbitrators etc. Their mission is to settle a conflict through dialogue outside court by means of mutual consent of parties involved.

H. Smit states that the prerogative of arbitration over litigation is the possibility to choose arbitrators of the necessary skills and relevant experience in the subject matter of the conflict (Smit, 1987). B. Cremades analysing international arbitration evolution, points out that in the $1970 \mathrm{~s}$ and $80 \mathrm{~s}$ this branch was considered to be an elite profession. He underlines that globalisation contributed to arbitration's success, leading to a rapid growth of strict competitive selection processes, checking the potential arbitrators' qualifications by different arbitral institutions including the International Chamber of Commerce and London Court of International Arbitration (Cremades, 1999). This proves the idea that arbitration has acquired a status of highly specialised international service, provided by professionals (Bond, 1991), in spite of the fact that M. Domke states that in most common law jurisdictions arbitrators are treated as quasi-judicial officers (Domke, 1971).
\end{abstract}


Ukrainian labor market lacks specialists who possess along with the knowledge and skills in arbitrage activities fundamental university legal training, allowing efficient settlement of international commercial disputes. The deficiency of such specialists degrades the realization of the integration and innovation processes in Ukraine.

Master's degree (LLM) in international arbitration is a logical completion of university education with further in-depth specialized training of a specialist in the field of international arbitration in Great Britain.

\section{THE AIM OF THE STUDY}

The aim of the article is to analyze, generalize and explain professionally important qualities of a Master's degree student in international arbitration.

\section{THEORETICAL FRAMEWORK AND RESEARCH METHODS}

So, the popularity of common law in international arbitration means that foreign theorists and practitioners have accumulated considerable experience in this field. The authors of works on international commercial arbitration are mostly researchers from abroad, in particular F. Davidson, A. Furrer, D. Girsberger, J. Knoll, J. Lew, M. Moses, Ch. Müller, J. Tackaberry and others.

However, there are many native authors (O. Brylev, K. Kokota, O. Melnyk, O. Pereverzeva, I. Pobirchenko, T. Slipachuk, O. Vysotskyi and others) who devoted their scientific activity to the study of theoretical, legal and practical framework for the implementation of international arbitration, substantiation of the importance of international commercial arbitration as a means of administering impartial justice.

Thus, the issue of professional education of arbitrators was left beyond national experts' attention, what causes the relevance of the chosen topic.

The method of analysis and synthesis of methodological, social, legal, scientificmethodical literature was applied to determine the state of readiness of the research problem. The method of generalization was used to formulate the conclusions of the article.

\section{RESULTS}

Master programes (LLM) in international arbitration at the outstanding British universities (School of International Arbitration, Queen Mary, University of London, King's College London School of Law, Department of Law of The London School of Economics and Political Science, University of East Anglia, Norwich Law School, University College London, Kingston University etc.) are aimed at training highly qualified specialists, with a high level of formation of key competencies.

Profound education of arbitrators enables them to become experts in arbitration law, with substantial knowledge of arbitration process, principles of activity of industryspecific arbitration institutions. General competence of a commercial arbitrator is demonstrated through combination of academic qualifications and professional arbitration expertise in the matters relevant to the dispute.

On the basis of the analysis of the relevant sources (Bond, 1991; Kelly, 2016; Bureau of Labor Statistics, 2016) a graduate of Master's degree program (LLM) in international arbitration must have the following competencies:

1) systemic competences:

- the ability of independent development of new research methods, to change scientific and scientific-professional profile of his/her activities;

- the ability to improve and develop his/her own intellectual and cultural level, to plan professional development and career;

- the ability to make management decisions, evaluate their possible consequences and bear responsibility for them; 
- the ability to analyze and assess the completeness of the information in the course of professional activities, if necessary, to fill and to synthesize the missing information;

- the ability to organize multilateral communication and manage it;

- the ability to maintain professional activities in the international arena;

2) professional instrumental competences:

- the ability to participate in law-making, law enforcement, expert consulting, managerial, research and teaching activities in the field of international arbitration;

- the ability to manage pre-hearing and hearing of the arbitration process to use the time and cost of the proceeding efficiently;

- the ability to manage separate fields of professional activity on the basis of legal and professional ethics;

- the ability to conduct written and oral communication in the agreed language of the arbitration;

- the ability to speak publicly (to negotiate) in the agreed language of the arbitration in the framework of professional and scientific interaction;

- the ability to create and edit valid and enforceable awards in the agreed language of the arbitration;

- the ability to execute and present the results of professional legal and scientific activities in accordance with the rules of legal technique, legal and local acts, international standards of business communication;

- the ability to obtain, sort and retrieve the legally significant information through the use of formal legal, comparative legal and other special methods of cognition.

3) professional social and personal competences:

- the ability to define, transmit legal and ethical standards in professional practice;

- the ability to define, transmit common goals in a professional legal capacity;

- the ability to make a conscious choice of the strategies of interpersonal interaction in the process of implementation of the professional activity;

- the ability to solve worldview, social and personally important problems;

- the ability to build professional arbitrage activity on the basis of principles of legality, fairness, neutrality and social responsibility;

- the ability to formulate and responsibly monitor the implementation of standards in professional arbitrage practice;

- the ability to generate new solutions, possess creativity, initiative, autonomy;

- the ability to maintain discretion throughout the proceedings and in the decision;

- the ability to work effectively in high stress situations.

After completion of the Master's degree program in Internation arbitration a graduate must possess the following:

knowledge of

- lexical and grammatical peculiarities of the English language to conduct effective professional communication;

- psychological peculiarities of an individual, psychological investigation methods, handling of a personality with mental health problems;

- legal and normative international and local documents;

- the content of major contemporary theoretical concepts of international arbitration;

- main trends in development of modern international arbitration;

- factors and conditions that determine the genesis of the sectors and institutions of arbitration law;

- the development status of the key problems of international arbitration in scientific literature; 
abilities

- to identify patterns and dynamics of development of international arbitration in modern conditions;

- to link theoretical and legal knowledge with the practical problem of improving the economic-legal problems;

- to analyze the legal sources of international nature;

- to analyze the existing legislation on international arbitration;

- to identify and settle problems relevant to professional activities;

- to apply effective research methods, to modify existing ones and to develop new methods, resulting from specific tasks of the study;

- to analyze and interpret the obtained results on the basis of the available literary data; reasoning);

- to apply general rules to specific problems to make sensible conclusions (deductive

- to analyze a set of premises to form general conclusions (inductive reasoning);

- to comprehend information and ideas presented orally;

- to use technological devices to fulfil professional tasks effectively;

skills of

- conducting negotiation applying relevant persuasion techniques;

- communicative skills which include active listening, speaking and writing;

- critical thinking to search for the best solutions, conclusions or approaches to problems.

\section{CONCLUSIONS}

Therefore, nowadays, international arbitration is a highly specialised service of alternative dispute resolution rendered by professionals. Master's degree program (LLM) completion enables interested persons (even those with the initial non-legal background) to become competent and competitive specialists in international arbitration.

Many leading British universities, having accumulated broad practical experience in organizing professional training in the field of international arbitration, offer prospective students master programs in this speciality. Systemic competences, professional instrumental competences, professional social and personal competences should be formed after LLM graduation. These competences must be supported by necessary knowledge, abilities and skills.

Further investigation perspective is the comparative analysis of the research problem in Western and Eastern Europe.

\section{REFERENCES}

1. Bond, S. R. (1991). The International Arbitrator: From the Perspective of the ICC International Court of Arbitration. Northwestern Journal of International Law \& Business, No 12 (1), pp. 1-23.

2. Bureau of Labor Statistics. (2016). Occupational Outlook Handbook 20162017. U.S. Department of Labor. Retrieved 14.05.2016 from : http://www.bls.gov/OOH/ legal/arbitrators-mediators-and-conciliators.htm.

3. Cremades, B. M. (1999). International Arbitration: a Key to Economic and Political Development. International Arbitration Law Review, No 5-6, pp. 145-150.

3. Domke, M. (1971). The Arbitrator's Immunity From Liability: A Comparative Survey. University of Toledo Law Review, No 3, pp. 99-103.

4. Kelly, B. (2016). Qualities of a Good Arbitrator. Retrieved 15.05.2016 from : http://everydaylife.globalpost.com/qualities-good-arbitrator-13527.html.

5. Smit, H. (1987). The Future Of International Commercial Arbitration: A Single Transnational Institution? Columbia Journal of Transnational Law, No 25 (9), pp. 9-34. 